\title{
IMPLEMENTASI KURIKULUM 2013 DALAM PELAKSANAAN PEMBELAJARAN SAINTIFIK DAN TEMATIK INTEGRATIF DI SDN SE-KOTA BANJARMASIN
}

\author{
Hamsi Mansur $^{1}$; $^{\text {Mastur }}{ }^{2}$ \\ Program Studi Teknologi Pendidikan, Universitas Lambung Mangkurat \\ Email: hamsimansur58@gmail.com
}

\begin{abstract}
Abstrak
Penelitian ini bertujuan untuk mendeskripsikan: (a) perencanaan pembelajaran, (b) pelaksanaan pembelajaran, (c) pelaksanaan penilaian, dan (d) faktor penghambat dan pendukung pelaksanaan pembelajaran dalam rangka mengimplemintasikan Kurikulum 2013 di SDN Se-Kota Banjarmasin. Penelitian ini menggunakan pendekatan deskriptif kualitatif. Subyek penelitian ini adalah personel yang berkaitan dengan implementasi Kurikulum 2013 dalam pelaksanaan pembelajaran di SDN Se-Kota Banjarmasin yang terdiri dari Kepala Sekolah, Wakil Kepala Sekolah bagian Kurikulum, Guru, dan Siswa. Pengumpulan data dilakukan melalui observasi partisipan, wawancara mendalam, dan dokumentasi. Hasil penelitian mengungkapkan 3 temuan. Pertama, perencanaan pembelajaran dilakukan dengan menerjemahkan ide dan konsep Kurikulum 2013 terlebih dahulu, kemudian disusunlah RPP yang dikembangkan secara rinci dari suatu materi pokok atau tema tertentu yang mengacu pada standar isi dan silabus. Kedua, pelaksanaan pembelajaran dilaksanakan dengan menggunakan pendekatan ilmiah (saintifik).. Ketiga, penilaian hasil belajar oleh guru dilakukan dengan menggunakan tes dan non-tes dalam bentuk tertulis maupun lisan, pengamatan kinerja, dan pengukuran sikap.
\end{abstract}

Kata-kata kunci: Implementasi Kurikulum 2013, Pelaksanaan Pembelajaran

\section{IMPLEMENTATION CURRICULUM 2013 IN SAINTIFIC AND TEMATIC INTEGRATIF LEARNING IN JUNIORS' SCHOOL BANJARMASIN}

\author{
Hamsi Mansur ${ }^{1}$ : Mastur $^{2}$ \\ Departement of Educational Technology, Lambung Mangkurat University \\ Email: hamsimansur58@gmail.com
}

\begin{abstract}
This research aims to describe: (a) the planning of learning, (b) the implementation of learning, (c) the implementation of the assessment, and (d) supporting the implementation of an inhibitor factor and learning in order to implemented Curriculum 2013 in Juniors' School Banjarmasin. This research uses descriptive qualitative approach. The subject of this research is the personnel with regard to the implementation of the curriculum 2013 learning in implementation Juniors' School Banjarmasin, which consists of the principal, vice principal of curriculum, teachers, and students. Data collection was done through participating observation, in-depth interviews, and documentation. The research results reveal the 3 findings. First, the planning of learning done by translating Curriculum 2013 ideas and concepts first, then RPP developed in detail of a particular theme or subject matter which refers to the standard content and syllabus. Second, the implementation of the study carried out using the scientific approach. Third, an assessment of the results of learning by teachers is carried out using a test and non-test in the form of written and oral observations, measurements, and performance demeanor.
\end{abstract}

Keywords: Implementation Curriculum 2013, Implementation Learning 


\section{PENDAHULUAN}

Pengembangan Kurikulum 2013 sangat erat berkaitan dengan kurikulum sebelumnya, yaitu kurikulum Tingkat Satuan Pendidikan (KTSP). Kurikulum yang menggunakan pendekatan terpusat pada bidang studi (subject-centered curriculum) ini sejak 2006 telah diterapkan di sekolahsekolah seluruh Indonesia. Karakteristik daripada KTSP ialah memilah struktur kurikulum ke dalam berbagai mata pelajaran yang dipandang perlu untuk peserta didik. Namun saat ini, kurikulum tersebut oleh pemerintah dianggap kurang mampu memenuhi kompetensi yang dibutuhkan untuk abad 21, abad yang dikenal dengan abad ilmu pengetahuan atau knowledgebased society. Kemudian, akhirnya tahun 2013 Pemerintah mengeluarkan Permendikbud Nomor 65 yang isinya perlunya dilakukan perubahan Standar Proses Pendidikan Dasar, Menengah dan Atas, serta juga mengisyaratkan wajibnya dilakukan perubahan sistem pembelajaran dan sistem penilaian sebagai implikasi dari perubahan pada standar proses.

Tema pembaharuan dan perbaikan pada Kurikulum 2013 yaitu ingin menciptakan manusia Indonesia yang mampu berfikir kreatif, produktif, inovatif, proaktif, dan afektif, melalui pengembangan sikap (tahu mengapa), keterampilan (tahu bagaimana), dan pengetahuan (tahu tentang apa) secara integratif. Pengintegrasian ini merupakan salah satu upaya memperbaiki peringkat
Indonesia dalam studi TIMSS (Trends in International Mathematics and Science Study) dan Program for International Student Assessment (PISA). Dimana, hasil studi TIMSS dan PISA pada 2011 peserta didik kita hanya mampu sampai level 3 dari 6 (enam) level kemampuan kognitif yang berkaitan dengan kemampuan berpikir tinggi (berpikir kritis, berpikir kreatif, analitis, sistematis dan logis untuk menemukan alternatif pemecahan masalah melalui eksplorasi data secara empiris dalam rangka menumbuhkan sikap ilmiah) semakin membaik dan meningkat. Begitupun juga kemampuan siswa Indonesia dalam memahami informasi yang kompleks, pemecahan masalah, pemakaian alat, prosedur, pemecahan masalah dan melakukan investigasi berada pada tingkat yang rendah.

Selain proses pembelajaran, sistem penilaian pun juga dikembangkan. Sistem penilaian pada Kurikulum 2013 diatur dalam Permendikbud Nomor 66 Tahun 2013, yang dimana guru dan satuan pendidikan diwajibkan mengevaluasi hasil belajar siswa secara komprehensif, menyeluruh, komplek, dan valid. Salah satu alat ukur yang digunakan ialah menggunakan penilaian autentik. Penilaian autentik yaitu penilaian yang melibatkan siswa di dalam tugas-tugas autentik yang bermanfaat, penting dan bermakna yang selanjutnya dapat dikatakan sebagai penilaian performa (Abidin, 2013, p.81). Atau dalam definisi yang lain 
disebutkan bahwa, penilaian autentik adalah kegiatan menilai peserta didik yang menekankan pada apa yang seharusnya dinilai, baik proses maupun hasil dengan berbagai instrument penilaian yang disesuaikan dengan tuntutan kompetensi yang ada di standar kompetensi (SK) atau kompetensi inti (KI) dan kompetensi dasar (KD) (Kunandar, 2013, p.35).

Perubahan lain dalam Kurikulum 2013 terdapat pada elemen standar isi. Kurikulum 2013 menghapus istilah Standar Kompetensi mata pelajaran yang sebelumnya digunakan dalam KTSP, dan diganti dengan istilah Kompetensi Inti. Mata pelajaran tidak lagi disajikan secara terpisah, akan tetapi terintegrasi dalam bentuk tema (SD dan SMP). Untuk itulah kenapa kemudian Kurikulum 2013 ini dapat dikatakan sebagai integrated curriculum. Yang dimaksud integrated curriculum ialah meniadakan batas-batas antara berbagai mata pelajaran dan menyajikan bahan pelajaran dalam bentuk unit atau keseluruhan (Nasution, 2003, p.196).

Sehubungan dengan perubahan pendekatan pembelajaran dan penilaian di atas, implementasi Kurikulum 2013 tentunya tidak mudah. Penyempurnaan kurikulum yang dibarengi dengan perubahan struktur mata pelajaran, perubahan sistem pembelajaran, dan perubahan sistem penilaian selalu berhubungan dengan berbagai aspek dalam sistem pendidikan. Guru, kepala sekolah, waktu, sumber belajar, dan sarana prasarana sekolah merupakan unsur yang berkaitan langsung dengan penerapan Kurikulum 2013. Jika perubahan kurikulum tidak dibarengi dengan perbaikan sarana prasarana, akses sumber belajar yang mudah dan berkualitas, dan peningkatan kompetensi serta perubahan mindset guru, maka upaya peningkatan mutu pendidikan hanya sia-sia belaka. Sebagaimana dijelaskan Anita Lie (2012) bahwa keberhasilan suatu kurikulum merupakan proses panjang, mulai dari kristalisasi berbagai gagasan dan konsep ideal tentang pendidikan, perumusan desain kurikulum, serta sarana dan prasarana, tata kelola pelaksanaan kurikulum, termasuk pembelajaran, penilaian pembelajaran, dan persiapan pendidik dan tenaga kependidikan.

Kemudian pertanyaannya sekarang, dengan perubahan dan perbaikan pada kegiatan pembelajaran dan penilaian tersebut, apakah pelaksanaan Kurikulum 2013 di SD berjalan dengan baik? Tidak kah ada kesulitan atau kendala bagi guru dalam melaksanakan pembelajaran saintifik, tematik integratif, dan penilaian autentik? Sudah layak kah SDN Se-Kota Banjarmasin dijadikan prototipe implementasi Kurikulum 2013?

Berangkat dari pertanyaan di atas, kiranya sangat menarik apabila dikaji secara mendalam perihal pelaksanaan pembelajaran saintifik, penilaian autentik dan mengetahui problematika dalam penerapan Kurikulum 2013 di SDN Se-Kota Banjarmasin. Oleh 
karenanya dalam penyusunan tesis ini penulis mengangkat judul "Implementasi Kurikulum 2013 dalam Pelaksanaan Pembelajaran di SDN Se-Kota Banjarmasin".

\section{METODE PENELITIAN}

Penelitian ini merupakan penelitian deskriptif dengan desain kualitatif. Menurut Sukmadinata (2012: 72), penelitian deskriptif adalah penelitian yang berusaha mendeskripsikan fenomena yang ada, baik fenomena yang bersifat alamiah atau rekayasa manusia. Sedangkan kualitatif merupakan penelitian yang menghasilkan teori yang timbul dari data bukan hipotesis. Penelitian deskriptif kualitatif yang dimaksud adalah dengan menghimpun data atau informasi sebanyak-banyaknya, bersifat deskriptif, lebih mementingkan proses daripada hasil, membatasi studi dengan fokus, memiliki seperangkat kriteria untuk memeriksa keabsahan data, rancangan penelitiannya bersifat sementara dan hasil penelitiannya disepakati oleh kedua pihak, baik oleh peneliti dan subjek penelitian.

Pemilihan pendekatan penelitian ini didasarkan atas pertimbangan bahwa data yang hendak dicari adalah data yang menggambarkan implementasi Kurikulum 2013 untuk tataran tingkat sekolah kemudian diperdalam pada implementasi kurikulum tingkat kelas yaitu pada pelaksanaan pembelajaraannya yang dimulai dari proses perencanaan, pelaksanaan, dan penilaian hasil belajar di SD $\mathrm{N}$ se Banjarmasin. Penelitian ini dilaksanakan di SDN Se-Kota Banjarmasin. Sedangkan waktu penelitian dilaksanakan mulai bulan Agustus 2015 (untuk pra-survei) dan dari bulan September 2015 (penelitian) dan berlangsung hingga titik keajegan pada bulan Desember 2015.

Dalam Penelitian ini yang menjadi subjek penelitian adalah personel yang berkaitan dengan implementasi Kurikulum 2013 dalam pelaksanaan pembelajaran di SDN Se-Kota Banjarmasin antara lain: Kepala Sekolah, Waka Kurikulum, Fasilitator dan Pendamping Kurikulum 2013. Masing-masing 3 orang Guru Matematika, IPA, IPS, dan Bahasa Indonesia yang jumlahnya secara keseluruhan 12 orang Guru Pata Pelajaran. Kemudian, terdapat 12 siswa yang berhasil dimintai keterangan antara lain: 4 orang kelas VII, 4 orang kelas VIII, dan 4 orang siswa kelas IX. Sedangkan objek penelitian ini adalah Implementasi Kurikulum 2013 dalam pelaksanaan pembelajaran di SDN Se-Kota Banjarmasin. Pelaksanaan pembelajaran yang dijadikan objek adalah kegiatan perencanaan, pelaksanaan, dan penilaian hasil belajar siswa yang merupakan satu kesatuan.

Dalam suatu penelitian diperlukan adanya suatu data sebagai hasil akhir dari penelitian. Untuk pengumpulan data yang kongkrit penulis melaksanakan beberapa teknik dan instrument pengumpulan data sebagai berikut: 
Pertama, dalam penelitian ini, peneliti menggunakan teknik pengumpulan data observasi partisipasi pasif dimana peneliti datang ke tempat kegiatan, namun tidak ikut terlibat di dalamnya. Observasi yang dilakukan pada saat proses pembelajaran berlangsung meliputi kegiatan kegiatan prainstruksional sampai kegiatan penutup. Peneliti juga melakukan observasi terhadap teknik penilaian yang digunakan oleh guru, serta kemungkinan hambatan dan upaya yang dilakukan oleh guru untuk mengatasi hambatan yang ditemui saat proses pembelajaran berlangsung. Dalam melakukan observasi, peneliti dilengkapi lembar observasi. Lembar observasi yang digunakan dalam penelitian ini yaitu; observasi guru mengenai perencanaan pembelajaran, pelaksanaan pembelajaran, dan penilaian hasil belajar siswa serta dilengkapi dengan pedoman observasi kegiatan siswa dalam pembelajaran.

Kedua, selain menggunakan observasi, peneliti juga menggunakan wawancara. Teknik wawancara yang digunakan dalam penelitian ini menggunakan wawancara semi terstruktur. Jenis wawancara ini tergolong dalam kategori in-dept interview, yaitu dalam pelaksanaannya lebih bebas bila dibandingkan dengan wawancara terstruktur. Sebelum melakukan kegiatan wawancara, terlebih dahulu peneliti membuat pedoman wawancara dengan tujuan agar proses tetap terfokus dan tidak keluar dari kontek yang menjadi tujuan utama peneliti. Informan yang dipilih oleh peneliti dalam penelitian ini adalah kepala sekolah, waka kurikulum, pendamping Kurikulum 2013, guru, dan siswa.

Ketiga, studi dokumentasi. Studi dokumentasi digunakan untuk melengkapi penggunaan metode observasi dan wawancara dalam penelitian deskriptif. Studi dokumentasi dalam penelitian ini dilakukan untuk memperoleh data mengenai perencanaan pembelajaran, pelaksanaan pembelajaran, dan penilaian hasil belajar siswa. Dalam penelitian ini, peneliti mendokumentasikan proses pembelajaran saintifik di kelas 7, 8 dan 9. Kemudian juga, peneliti mengambil dokumen-dokumen yang berupa profil sekolah, rencana pelaksanaan pembelajaran (RPP), instrument penilaian, daftar nilai dengan teknik penilaian Kurikulum 2013, dan laporan tahuan sekolah untuk memperoleh data dokumentasi.

Pengujian keabsahan data dilakukan dengan cara ketekunan/keajegan pengamatan, trianggulasi data dan auditing atau pemeriksaan data. Berkaitan dengan hal tersebut, maka langkah-langkah yang ditempuh dalam pengujian keabsahan data sebagai berikut:

Pertama, ketekunan pengamatan bermaksud menemukan ciri-ciri dan unsurunsur dalam situasi yang sangat releven dengan persoalan atau isu yang sedang dicari dan kemudian memusatkan diri pada 
hal-hal tersebut secara rinci. Keajegan pengamatan diupayakan mencari secara konsisten interpretasi dengan berbagai cara dalam kaitan dengan proses analisis yang konstan dan tentatif, dengan cara mencari konsistensi apa yang dapat diperhitungkan dengan apa yang tidak dapat, agar data betul-betul valid, akurat, dan bisa dipertanggungjawabkan.

Kedua, triangulasi data yaitu memeriksa keabsahan data melaui sumber, teknik dan teori. Triangulasi sumber memungkinkan peneliti melakukan pengecekan ulang dan melengkapi informasi dengan sumber-sumber lainn. Triangulasi sumber dalam penelitian ini dilakukan antara kepala sekolah, guru, dan siswa. Triangulasi teknik prosesnya dengan menguji kredibilitas data yang dilakukan dengan cara mengecek data kepada sumber yang sama namun dengan teknik yang berbeda. Data yang diperoleh dengan wawancara, kemudian dicek dengan data yang diperoleh dari observasi, dan dokumentasi. Triangulasi teknik yang digunakan oleh peneliti dalam penelitian ini adalah antara observasi, wawancara dan dokumentasi. Triangulasi dengan teori digunakan untuk mempertajam analisis penelitian dengan memeriksa derajat kepercayaan data.

\section{HASIL DAN PEMBAHASAN}

Proses penelitian di lapangan yang tidak terlalu berjalan dengan mulus dan tidak mudah karena berbagai faktor, telah sampai pada proses akhir yaitu penyajian data. Data-data di bawah ini merupakan sekumpulan data yang diperoleh dari hasil pengamatan, observasi, wawancara dan telaah dokumen. Data-data di bawah ini tentunya sudah melalui berbagai rangkain kaidah penelitian seperti, ketekunan, keajegan pengamatan, trianggulasi data, dan auditing. Langkah-langkah tersebut kemudian dilanjutkan dengan analisis data dengan menyeleksi, menentukan fokus, menyederhanakan dan mentransformasikan data yang muncul pada catatan lapangan. Beberapa poin penting yang dianalisis ialah pada perencanaan pembelajaran, pelaksanaan pembelajaran, penilaian hasil belajar, dan hambatan serta kendala dalam pelaksanaan pembelajaran. Untuk itu, berikut hasil data-data implemintasi kurikulum 2013 di SD N se Banjarmasin dalam pembelajaran setelah melalui serangkaian proses analisis tersebut. Dalam hal perencanaan pembelajaran, data-data yang diperoleh adalah sebagai berikut:

Pertama, semua guru di SDN Se-Kota Banjarmasin menyusun RPP untuk mata pelajaran yang diampunya. Pengembangan RPP dikembangkan atau disusun di setiap awal semester atau awal tahun pelajaran. Hal ini ditujukan agar agar RPP (rencana pelaksanaan pembelajaran) telah tersedia terlebih dahulu dalam setiap awal pelaksanaan pembelajaran.

Kedua, pengembangan RPP oleh guru SDN Se-Kota Banjarmasin dilakukan secara mandiri dan secara bersama-sama melalui 
kelompok kerja guru (gugus). Di antara kegiatan penyusunan RPP yang dilakukan bersama musyawarah guru mata pelajaran antara lain; kegiatan pengkajian silabus dengan mengkaji KI dan KD, mengkaji materi pembelajaran, mengkaji proses pembelajaran, mengkaji penilaian pembelajaran, mengkaji alokasi waktu, dan mengkaji sumber belajar.

Ketiga, berbagai persoalan keterlambatan pendistribusian buku pegangan guru dan buku pegangan siswa serta persoalan kesalahan konsep dan kedangkalan materi kurikulum 2013 menjadikan buku K-13 bukan sebagai sumber rujukan utama dalam proses pembelajaran di dalam kelas. Kemudian untuk mengembangkan materi pelajaran, guru-guru bersama siswa mengembangkan materi pelajaran selain dari buku teks pelajaran dan buku panduan guru juga dikembangkan dari sumber Internet, alam sekitar, ahli/professional, dan berbagai sumber belajar yang lainnya (museum, ritel, dan tempat-tempat bersejarah).

Keempat, RPP yang dibuat mengedepankan perencanaan pembelajaran yang nantinya dalam proses belajar mengajar akan mendorong partisipasi aktif siswa. RPP yang dibuat selalu berusaha agar tidak menyimpang dari tujuan Kurikulum 2013 yaitu dengan menggunakan pendekatan saintifik. Proses pembelajaran dilakukan bertujuan untuk menghasilkan siswa yang mandiri dan tidak berhenti belajar, proses pembelajaran yang berpusat pada siswa (student centered) sehingga dapat mengembangkan motivasi, minat, rasa ingin tahu (curiousity), kreativitas, inisiatif, inspirasi, kemandirian, semangat belajar, keterampilan belajar dan kebiasaan belajar.

Kelima, di dalam menentukan alokasi waktu untuk setiap KD didasarkan pada jumlah minggu efektif dan alokasi waktu mata pelajaran setiap minggu yang tersedia dengan tetap mempertimbangkan jumlah $\mathrm{KD}$, keluasan, kedalaman, tingkat kesulitan, dan tingkat kepentingan KD. Alokasi waktu yang dirinci dalam RPP mengacu pada yang dituliskan.

Keenam, guru-guru SDN Se-Kota Banjarmasin mengembangkan sendiri penilaian pembelajaran dengan menentukan lingkup, teknik, dan instrument penilaian. Selain itu juga, guru-guru dengan sendirinya mengembangkan pedoman penskoran yang akan digunakan menilai hasil belajar siswa.

Ketujuh, pengembangan RPP di SDN Se-Kota Banjarmasin tidak pakem. Guruguru diberikan kebebasan berkreasi sesuai dengan ide dan kreatifitasnya. Kepala sekolah menyarankan untuk mengambil semangat implemintas kurikulum 2013 daripada guru-guru disibukkan menyiapkan perangkat pembelajaran dan penilaian yang dianggap terlalu administratif dan menyita banyak waktu guru-guru. Dalam prosesnya, Kepala sekolah SDN Se-Kota Banjarmasin lebih mengutamakan kualitas pelaksanaan dan hasil daripada kualitas perencanaan. 
Dalam hal pelaksanaan pembelajaran, datadata yang diperoleh adalah sebagai berikut:

Pertama, guru memfasilitasi siswa memunculkan gagasan baru. Dari beberapa kegiatan yang teramati di lapangan, tampak usaha-usaha yang dilakukan guru menfasilitasi siswa agar berani memunculkan gagasan baru. Misalnya, salah satu usaha yang dilakukan dengan mengajak siswa melakukan observasi di luar lingkungan sekolah dan memberikan keleluasaan kepada siswa dalam mengembangkan sumber belajar.

Kedua, guru menyampaikan materi dengan mudah difahami, menarik, dan menyenangkan. Meskipun tidak secara keseluruhan, dari hasil pengamatan ditemukan banyak guru SDN Se-Kota Banjarmasin yang mengusahakan sebuah kegiatan pembelajaran yang menarik, menyenangkan, dan mudah difahami. Usaha ini tampak dari upaya guru dalam memberikan memotivasi selama kegiatan pembelajaran. Dari hasil pengamatan peneliti, guru selalu menggunakan kata-kata motivasi untuk menambah semangat dan etos belajar siswa.

Ketiga, Guru menggunakan beragam strategi pembelajaran. Berdasarkan hasil wawancara dengan kepala sekolah SDN SeKota Banjarmasin, sekolah memberikan kesempatan seluas-luasnya kepada guru untuk mengembangkan strategi pembelajaran yang sesuai dengan karakteristik masing-masing mata pelajaran yang mereka ajarkan. Sekolah tidak membatasi guru menggunakan strategi tertentu. Sebab dengan menggunakan pendekatan saintifik, tentunya guru sudah memahami strategi pembelajaran yang sesuai dengan pendekatan tersebut (15/12/2015).

Dari hasil pengamatan peneliti di dalam kelas, dan juga berdasarkan dokumen RPP yang dirancang dan dirumuskan ada banyak strategi yang digunakan oleh guru. Beberapa strategi tersebut diantaranya ialah projek base learning, pembelajaran kontekstual, dan pembelajaran koperatif. Pada kesempatan yang lain, wawancara dilakukan dengan waka kurikulum. Dalam sebuah wawancaranya dinyatakan bahwa, untuk menentukan strategi pembelajaran, sekolah memberikan wewenang penuh pada guru dalam menentukan strategi pembelajaran yang mereka gunakan dalam pembelajaran. Sekolah hanya mengatur waktu/memberikan waktu kepada guru dalam proses pembelajaran, namun dalam praktiknya di kelas, guru diberikan kebebasan penuh.

Keempat, guru menggunakan beragam media pembelajaran. Penggunaan media pembelajaran tampak dari kegiatan-kegiatan pembelajaran di atas. Beberapa diantaranya seperti pada kegiatan pendahuluan, siswa mengamati, mengumpulkan informasi, dan kegiatan siswa dalam mengkomunikasikan hasil belajarnya. Penggunaan media pembelajaran dalam setiap kegiatan 
pembelajaran di SDN Se-Kota Banjarmasin menjadi sebuah keharusan bagi guru-guru. Meskipun terkadang dalam kondisi tertentu dari hasil pengamatan peneliti, masih terdapat guru yang minimalis dalam memanfaatkan media pembelajaran, misalnya hanya berupa papan tulis dan alat peraga sederhana lainnya. Akan tetapi, hal ini persentasenya lebih sedikit daripada guru yang memanfaatkan media.

Kelima, guru menggunakan beragam sumber belajar lain. Dari hasil pengamatan peneliti untuk beberapa kegiatan pembelajaran yang diamati, tampak proses pembelajaran tidak lagi bergantung pada guru sebagai sumber utama atau sumber tunggal dalam kegiatan pembelajaran. Proses pembelajaran tidak lagi berbentuk proses komunikasi verbal antara guru dan siswa. Siswa diberikan kesempatan menjadi sumber belajar untuk kegiatan pembelajaran di dalam kelas. Hal ini tampak ketika guru mengarahkan dan menganjurkan agar siswa menggali referensi materi pelajaran dari berbagai sumber, mulai dari buku teks pelajaran, sumber online, hingga memperoleh langsung dari ahlinya/maestronya.

Dari beberapa sumber yang diperoleh, siswa diarahkan dan dimotivasi agar berani menyampaikan temuan-temuannya baik di depan kelas maupun ditengah-tengah temannya. Misalnya guru memberikan tugas individu mempresentasikan sebuah makalah berkaitan dengan materi yang akan dipelajari atau membuat diskusi kelompok dengan menghadirkan berbagai sumber sebagai dasar bahan diskusi. Kondisi seperti ini, serinkali teramati oleh peneliti dalam kegiatan observasi atau pengamatan di dalam kelas.

Keenam, guru memfasilitasi peserta didik untuk memperoleh pengalaman yang bermakna. Ada beberapa upaya guru agar siswa tidak hanya tahu hal-hal yang bersifat abstrak. Beberapa diantara upaya itu ialah; 1) melibatkan peserta didik mencari informasi yang luas dan dalam tentang topik/tema materi yang akan dipelajari, 2) menggunakan pendekatan pembelajaran saintifik, 3) menghadirkan beragam media pembelajaran dan sumber belajar lain, 4) memfasilitasi terjadinya interaksi antar peserta didik serta antara peserta didik dengan guru, lingkungan, dan sumber belajar lainnya, 5) melibatkan peserta didik secara aktif dalam setiap kegiatan pembelajaran, 6) memfasilitasi peserta didik melakukan percobaan di laboratorium, studio, dan lapangan.

Jika mengacu pada Permendikbud Nomor 66 Tahun 2013 beserta turunannya tersebut, maka dapat dikatakan guru-guru SDN Se-Kota Banjarmasin telah melaksanakan dan mengimplementasikan penilaian hasil belajar Kurikulum 2013. Hal ini dikarenakan adanya kesusaian antara teknik dan instrumen penilaian yang dilakukan guru dengan format penilaian yang ada pada Kurikulum 2013. Penilaian 
hasil belajar dalam yang dilakukan guruguru SDN Se-Kota Banjarmasin dilaksanakan dalam bentuk penilaian autentik dan penilaian non-autentik, tetapi pendekatan utama dalam penilaian hasil belajar oleh pendidik adalah penilaian komprehensif.

\section{KESIMPULAN DAN SARAN}

Berdasarkan pemaparan hasil penelitian dan pembahasan di atas, maka dapat disimpulkan sebagai berikut:

Pertama, perencanaan pembelajaran diawali dengan mengkaji Silabus dan merumuskan Indikator. RPP dikembangkan dari silabus untuk mengarahkan kegiatan pembelajaran peserta didik dalam upaya mencapai Kompetensi Dasar (KD). Penyusunan RPP dan instrumen penilaian dianggap terlalu administratif dan membutuhkan waktu yang banyak, sehingga bisa menghambat penyusunan materi dan strategi pembelajaran.

Kedua, pelaksanaan pembelajaran dilaksanakan dengan menggunakan pendekatan ilmiah (saintifik). Langkahlangkah dalam proses pembelajaran meliputi menggali informasi melaui pengamatan, bertanya, percobaan, kemudian mengolah data atau informasi, menyajikan data atau informasi, dilanjutkan dengan menganalisis, menalar, kemudian menyimpulkan, dan mencipta. Dalam prosesnya, pendekatan ini selain membutuhkan waktu yang banyak, juga dianggap kurang cocok diterapkan untuk mata pelajaran matematika secara sintak.

Ketiga, penilaian hasil belajar oleh guru dilakukan dengan menggunakan tes dan nontes dalam bentuk tertulis maupun lisan, pengamatan kinerja, pengukuran sikap, penilaian hasil karya berupa tugas, projek, penggunaan portofolio, dan penilaian diri. Pada proses pelaksanaannya format penilaian ini dianggap terlalu banyak dalam penggunaan waktu. Sehingga, alokasi waktu dalam melaksanakan pembelajaran menjadi kurang efektif karena harus berbagi dengan waktu penilaian peserta didik.

Secara umum implementasi Kurikulum 2013 di sekolah ini sudah berjalan sesuai dengan harapan. Hal ini tanpak dari pelaksanaan pembelajaran yang menggunakan pendekatan saintifik dan penilaian hasil pembelajaran dengan menggunakan penilaian autentik. Namun demikian ada beberapa aspek yang perlu dikembangkan menjadi lebih baik lagi. Oleh karena itu peneliti sarankan agar SDN SeKota Banjarmasin tetap berinovasi dan mengembangkan diri dengan terus meningkatkan mutu sekolah lebih baik.

\section{DAFTAR PUSTAKA}

Abidin, Y. (2013). Desain sistem pembelajaran dalam konteks Kurikulum 2013. Bandung: Rafika Aditama.

Fadlillah, M. (2014). Implementasi kurikulum 2013 dalam pembelajaran SD/MI, SMP/MTs, \& SMA/MA. Yogyakarta: ArRuzz Media.

Keyes, G. (2010). Teaching the scientific method in the social sciences. Journal of Effective Teaching, 2, 220-232. 
Nasution, S. (2003). Asas-asas kuriklum. Jakarta. Bumi Aksara.

Sukmadinata, N.S. (2012). Metode penelitian pendidikan. Bandung: Remaja Rosdakarya. 